\title{
人体熱負荷とその変動が睡眠に及ぼす影響 EFFECTS OF THERMAL LOAD AND ITS VARIATION ON SLEEP
}

\author{
海 野 賢*, 三宅 絵美香**, 田 辺 新一*** \\ Ken UNNO, Emika MIYAKE and Shin-ichi TANABE
}

\begin{abstract}
Different kinds of adaptive opportunities are selected in bedrooms, such as air conditioning and natural ventilation; however, the thermal environment created by these measures is not necessarily good for sleep. In this research, a field survey was carried out to investigate the effect of the total thermal environment and its variation on sleep. First, we investigated the effect of airflow and found that an increase in air turbulence causes an increase in the duration of wakefulness. Next, we adjusted the comfort equation for sleep and calculated the thermal load on the body and its variation. We found that both negative and positive increase in the heat load on the body causes an increase in the probability of awakening. An increase in its variation also resulted in an increase in the probability of awakening. We concluded that when planning a pleasant thermal environment for sleep, it is important to consider the total thermal environment and to take into account the effect of its variation as potential cause of sleep disruption.
\end{abstract}

Keywords: Sleep, Thermal Environment, Field Survey, Thermal Load on Body, Air Turbulence 睡眠，温熱環境，実測調査，人体熱負荷，気流の乱れの強さ

\section{1. はじめに}

睡眠は人間の健全な生活に不可欠であり、睡眠の質の低下は日中 の活動に影響を及ぼす 1）2）。睡眠の阻害要因として、精神的要素・ 社会的要素・環境的要素などが挙げられているが、中でも温熱環境 の影響は非常に大きい。レム睡眠期には体温調節機能が低下寸る ${ }^{3}$ ため、熱的中立状態でないときは体温調節の必要性からレム睡眠量 が減少する。結果として、自律神経系の眠りであるレム睡眠の減少 が学習成立の阻害につながる 4) 5)。温熱環境を改善するために約 9 割の人が夏季の就寝中にエアコンまたは扇風機を多様な運用法で使 用している ${ }^{6)}$ 。しかし、これらの環境適応行動により形成された温 熱環境は必ずしも良好な睡眠を得や寸い環境ではない可能性がある。 本研究では、自宅寝室における温熱環境実測調査と心理量・生理 量測定から総合温熱環境が睡眠に及ぼす影響を明らかにすることを 目的とした。実測結果から熱的中立状態であることに加え、気流や 温湿度が安定していることが睡眠の質を向上させることを示した。

\section{2 温熱環境と睡眠に関する既往研究}

\section{1. 空気温度と睡眠の質の関係}

温熱環境が睡眠に及ぼす影響に関する研究は多数行われている。 特に空気温度と睡眠の関係に関する研究が先行して行われてきた。

Haskel ら 7) は、様々な空気温度における裸体の被験者実験を行 い、空気温度の違いが入眠潜時に及ぼす影響は小さいこと、中途覚
醒及び段階 1 の浅い睡眠の発生時間は中性温度の $29^{\circ} \mathrm{C}$ において最 も短くなり、中性温度から離れるにつれて長くなることを示した。 加えて、低温環境下よりも高温環境下において、睡眠の質が低下寸 ることを示した。Muzet ら 8) は、環境温度が高いほどレム睡眠周期 が短くなること、レム睡眠周期は入眠直後から起床時に向かって 徐々に短くなる傾向があることを示した。加えて、レム睡眠時には 体温調節機能が低下寸るため、低温環境時には体温調節を行うノン レム睡眠時間を長くする必要があるとしている。Ohnaka ら 9) 神田 ら ${ }^{10)}$ は、室内空気温度が高いほど体動数が増加することを示した。

\section{2. 温熱環境の動的制御と睡眠の質の関係}

一夜を通じて温熱環境をどのように変動させると良好な睡眠を得 られるかを検討した研究も行われている。

川島ら 11) は、間欠冷房をした場合と冷房をしない場合で就寝中 の心理・生理反応に大きな差は見られないが、間欠冷房は安眠効果 が少ないことを示した。また、空気温度を $28 \sim 29^{\circ} \mathrm{C}$ 一定に制御し、 入眠時に相対湿度を $40 \%$ 前後とし、入眠から約 3 時間後に $60 \%$ 前後 に上昇させることが最適な湿度制御法であるとした。一方、垣鍔ら 12）は、相対湿度の変化による効果は期待できないとしている。加え て、睡眠の後半に起床後の体温上昇を促寸温熱環境条件が睡眠の質 を高める効果があることを示した。系井川ら 13) は、自律神経の安 定を得るためには空気温度 $26^{\circ} \mathrm{C}$ が効果的であり、起床時に高い睡 眠感を得るためには $28^{\circ} \mathrm{C}$ が効果的であることを示した。

\footnotetext{
* 鹿島建設(株)

(当時: 早稲田大学大学院創造理工学研究科建築学専攻 修士)

** 早稲田大学大学院創造理工学研究科建築学専攻 修士課程

*** 早稲田大学創造理工学部建築学科 教授.工博
}

Kajima Corporation.

(Former Grad. Stud., Dept. of Architecture, Waseda University)

Grad. Stud., Dept. of Architecture, Waseda University

Prof., Dept. of Architecture, Waseda University, Dr. Eng. 


\section{3. 気流と睡眠の関係}

気流が睡眠に及ぼす影響を評価した研究は多く行われていない。 川島ら 14） は、 $28^{\circ} \mathrm{C}$ 、相対湿度 $60 \%$ の高温湿環境では、気流曝露 が熱負荷を軽減し、静穏気流時に比べ心理・生理的にも睡眠の質を 向上させる効果があることを示している。Tsuzuki ら 15) は、高温 高湿環境下では気流によって直腸温、皮膚温の低下と発汗量の減少 が生じ、中途覚醒時間が短くなることを示した。一方で、森戸ら 16) は、放射冷房とエアコン冷房の比較を行い、エアコンの冷気流が皮 膚温低下を引き起こし、中途覚醒に繋がることを示している。

これらの研究では、温熱要素とその変化が睡眠に及ぼす影響の評 価を行っているが、適切とされる空気温度は様々である。その原因 として、寝具の熱抵抗を含む全ての温熱要素を加味した総合温熱環 境を定量的に評価していないことが挙げられる。就寝中の総合温熱 環境を定量化し、総合温熱環境と睡眠の質の因果関係を分析する必 要がある。また、温熱環境が定常となるように制御した実験や人為 的に温熱環境の変化を制御された実験が主として行われており、こ れらは実際の寝室で生じる温熱環境の変動とは異なる。実際の寝室 における温熱環境の変化が睡眠の質に及ぼす影響を評価した研究は ほとんど行われていない。

\section{3. 実測調査概要}

\section{1. 実測対象者及び実測調査期間}

睡眠習慣が規則的な平均年齢 22.4（土1.2）歳の学生 16 名（男性 11 名、女性 5 名) を対象とし、各実測対象者の自宅寝室で温熱環境・ 体動・心理量を測定した。実測対象者には普段通りの生活を送らせ、 就寝中のエアコン等の環境適応手法、温熱環境、生理的・心理的な 睡眠の質を調査した。環境適応手法とは、エアコン・扇風機・空開 け通風の使用の有無と使用方法のことをいう。実測期間は 2013 年 9 月 2 日から 10 月 26 日とし、各実測対象者は、連続する平日 5 日間 の実測調查を 9 月（9月 2 日 9 月 28 日）と 10 月（9月 30 日 10 月 26 日）に一回ずつ行った。実測調查は同時に 4 名ずつ実施した。

\section{2. 環境適応手法及び着衣と寝具の使用状況調査}

実測調查期間中は毎日起床時に、エアコン・扇風機・空開け通風 の中から環境適応手法を申告させた。なお、エアコン・扇風機に関 しては設置位置と風量設定及び吹出し方向を申告させた。また、そ の環境適応手法を選択した理由も申告させた。寝具と着衣の熱抵抗 に関しては、Lin ら 17)によって測定された寝具の種類と掛け方を申 告用紙に提示し、最も近いものを就床時と起床時に申告させた。

\section{3. 心理量測定}

心理量測定は申告用紙を配布し、就床時と起床時にベッド(布団) 上で申告させ、就床時と起床時にベッド（布団）上における温熱環 境を評価した。就寝中の心理量に関しても起床時に申告させた。就 床時、就寝中、起床時について温冷感、熱的快不快感、気流感、そ の気流環境に対する快不快感及び気流の温度・強さについてどのよ うにあって欲しいかを申告させた。加えて、就床時の疲労感、起床 時の睡眠に対する満足度を申告させた。

\section{4. 生理量測定}

実測対象者の非利き腕に腕時計型体動計（Actiwatch 2) を装着さ せ、体動を 30 秒間隔で測定した。測定結果から睡眠と覚醒の判定 を行い、入眠潜時、中途覚醒時間、中途覚醒回数等を算出した。

\section{表 1 温熱環境測定項目}

\begin{tabular}{|c|c|c|}
\hline 温熱環境測定項目 & 測定機器 & 測定間隔 \\
\hline 空気温度 $\left.{ }^{A}\right)$ & 小型温湿度計 & $1 \mathrm{~min}$ \\
\hline 相対湿度 ${ }^{A)}$ & 小型温湿度計 & $1 \mathrm{~min}$ \\
\hline グローブ温度B) & 簡易グローブ球 & $1 \mathrm{~min}$ \\
\hline 気流速度 $\left.{ }^{-}\right)$ & $\operatorname{Tr}$ 式微風速計 & $10 \mathrm{sec}^{\text {注） }}$ \\
\hline
\end{tabular}

A) Espec Thermo Recorder RSW-20S

B) Espec Thermo Recorder RTW-30S

C) Digital Anemometer AM-03

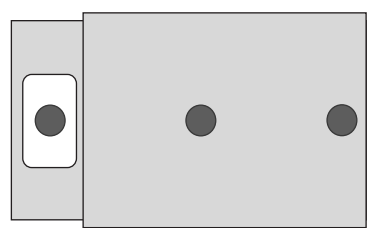

就床時・起床時
注） 10 秒間隔の平均值を測定

主) 測定高さはベッド(布団) 上面程度とした

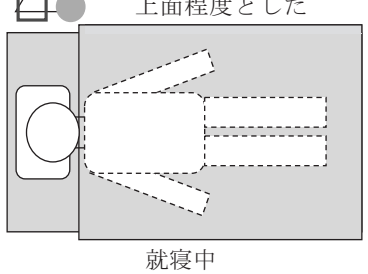

$\square$ 小型温湿度計 $\bigcirc$ 簡易グローブ球 $\bigcirc$ Tr式微風速計

図 1 温熱環境測定位置

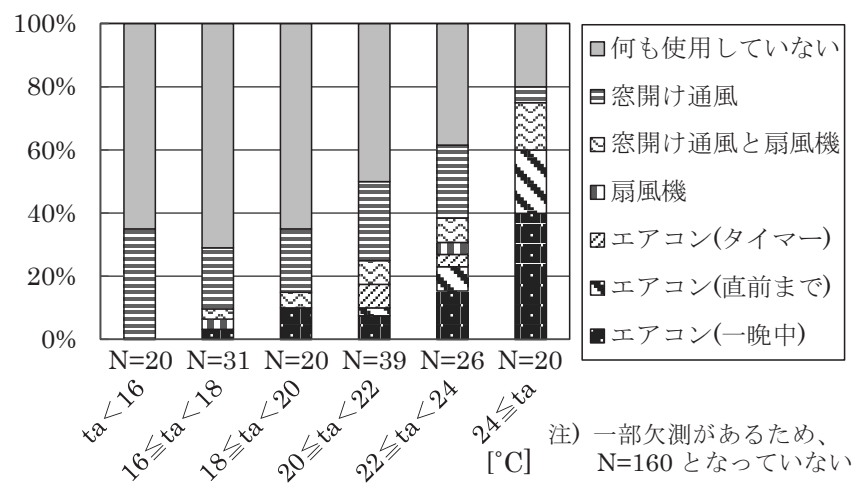

図 2 就寝中の平均外気温ごとの環境適応手法の割合

\section{5. 温熱環境測定}

表 1 に温熱環境測定項目、図 1 に温熱環境測定位置を示す。空気 温度、相対湿度、黒色グローブ温度、気流速度を測定した。測定間 隔は、気流速度を除き 1 分間隔の瞬時值とし、気流速度のみ 10 秒 間の平均值とした。各要素の測定位置は就寝中に温熱環境の影響を

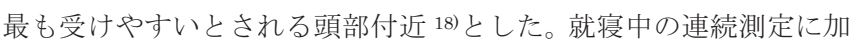
え、部位別の気流速度を調查するために就床時及び起床時に寝具の 頭部・腹部・足部の気流速度を 5 分間ずつ測定し、測定結果から測 定開始直後と終了直前の 1 分間ずつを除く 3 分間の気流速度から平 均気流速度を算出した。

\section{4. 実測調査結果}

\section{1. 環境適応手法}

図 2 に就寝中の平均外気温 $t_{a}$ ごとの環境適応手法の割合、表 2 に 環境適応手法ごとの就寝中の平均温熱環境を示す。平均外気温は各 自宅最寄りの気象台の測定值 19) を用いた。平均外気温が高いほど 「エアコン」の使用率が高くなり、「何も使用していない」割合が低 下した。このように、「暑さ」に対する環境適応が行われたため、い ずれの環境適応手法使用時も平均空気温度が $27^{\circ} \mathrm{C}$ 以下であったと 推測している。また、空気温度が比較的高いときには扇風機の利用 や、着衣と寝具の熱抵抗を小さくするといった、環境適応手法や着 衣と寝具の選択による適応行動が行われていた。 


\section{2. 生理量}

全実測対象者の平均総就床時間は 6 時間 14 分、平均睡眠効率は $87.6 \%$ 、中途覚醒時間（WASO）を睡眠時間（SPT）で除して算出 した平均の単位時間あたりの中途発生率は $6 \%$ であった。

\section{3. 温熱環境要素}

\section{1）空気温度}

図 3 に実測対象者 $\mathrm{C}$ の代表日における空気温度の経時変化を示寸。 「エアコン (一晚中)」を使用していたため、その発停により空気温 度は変動を繰り返した後、7 時頃から起床時刻にかけて $2^{\circ} \mathrm{C}$ 以上低 下した。空気温度が大きく下降した時に中途覚醒が生じており、温 熱環境の変化が覚醒刺激となっていることが推測できる。

2) 気流の乱れの強さ

Fanger ら 20) によって気流の乱れの強さが、気流不快感に影響す ることが示されている。そこで、気流の乱れの強さ $T u$ が睡眠に及 ぼす影響を検討した。なお、Fanger らは、0.1 秒間隔で測定した気 流速度から算出した標準偏差と平均から式（1）により算出した值 を気流の乱れの強さ $T u$ としているが、本研究では、10 秒間隔で測 定した気流速度から算出した標準偏差と平均から気流の乱れの強さ を算出した。気流の乱れの強さの算出式を式（1）に示す。

$$
T u=\frac{S D_{v}}{\bar{v}} \times 100 \quad[\%]
$$

$S D_{v}$ : 気流速度の標準偏差 $[\mathrm{m} / \mathrm{s}] \quad \bar{v}$ : 気流速度の平均值 $[\mathrm{m} / \mathrm{s}]$

図 4 に実測対象者 $\mathrm{A}$ の代表日における 10 分あたりの気流の乱れ の強さと 10 分あたりの中途覚醒時間の経時変化を示す。平均気流 速度は $0.06 \mathrm{~m} / \mathrm{s}$ と比較的弱く、気流の乱れの強さの平均值は $11.7 \%$ であった。空開け通風を利用していたため、屋外の影響を受けて気 流の乱れが $30 \%$ を超える時間帯もあり、気流の乱れが強くなった時 に中途覚醒時間が長くなる傾向がみられた。他の実測対象者におい ても気流の乱れが強いときに中途覚醒が発生する傾向がみられた。

図 5 に 10 分あたりの気流の乱れの強さと中途覚醒発生率の関係 を示す。気流の乱れの強さを $5 \%$ 刻みに分類し、その区分内での中 途覚醒発生率の平均值を示した。なお、プロットの大きさは区分内 の測定数を表し、プロット 1 つにつき 25 以上の測定数のもののみ プロットした。気流の乱れが強いほど中途覚醒発生率が高くなるこ とが示された。気流の乱れの強さ $T u$ に起因する中途覚醒発生率 $P W_{T u}$ は式 (2) で表される。なお、近似直線の切片は、気流の乱れ の強さTu以外の要因に起因する中途覚醒発生率 $C_{T u}(=6.6 \%)$ である。

$$
P W_{T u}=0.2011 T u \quad[\%]
$$

\section{5. 総合温熱環境が睡眠の質に及ぼす影響}

\section{1. 総合温熱環境と中途覚醒発生率の関係に関する仮説}

各温熱要素が睡眠に及ぼす影響は様々な研究で検討されているが、 総合温熱環境が睡眠に及ぼす影響の検討はほとんど行われていない。 そこで、本研究では人体熱負荷 $L$ を用いて総合温熱環境を評価する。

既述したように暑さや寒さに加え、温熱環境の変化が覚醒刺激と なることが予想される。そこで、中途覚醒発生率は人体熱負荷 $L$ 及 び人体熱負荷の変化率 $\frac{d L}{d t}$ で説明できるという仮説を立てた。 1 分間 隔の人体熱負荷 $L$ 及びその変化率 $\frac{d L}{d t}$ と当該時刻の睡眠と覚醒の判 定結果を用いて、各時刻における人体熱負荷 $L$ 及びその変化率 $\frac{d L}{d t}$ と 中途覚醒発生率の関係を検討した。

\begin{tabular}{|c|c|c|c|c|}
\hline 環境適応手法 & 空気温度 $\left[{ }^{\circ} \mathrm{C}\right]$ & 放射温度 $\left[{ }^{\circ} \mathrm{C}\right]$ & 相対湿度 [\%] & 気流速度 $[\mathrm{m} / \mathrm{s}]$ \\
\hline $\begin{array}{l}\text { エアコン } \\
\text { (一晚中) }\end{array} \quad(\mathrm{N}=18)$ & $25.6 \pm 2.8$ & $25.1 \pm 2.6$ & $63 \pm 10$ & $0.07 \pm 0.03$ \\
\hline 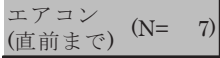 & $26.8 \pm 1.0$ & $27.1 \pm 13.2$ & $56 \pm 6$ & $0.07 \pm 0.04$ \\
\hline $\begin{array}{l}\text { エアコン } \\
\text { (タイマー) }\end{array}(\mathrm{N}=\quad 4)$ & $26.4 \pm 0.6$ & $26.7 \pm 13.4$ & $68 \pm 3$ & $0.06 \pm 0.04$ \\
\hline$(\mathrm{N}=2)$ & $25.1 \pm 3.1$ & $24.9 \pm 3.2$ & $60 \pm 1$ & $0.33 \pm 0.28$ \\
\hline $\begin{array}{l}\text { 空開け通風 } \\
\text { と扇風機 }\end{array}$ & 27.0 & $27.1 \pm 8.4$ & 1 & $0.27 \pm 0.18$ \\
\hline 空開け通風 $(\mathrm{N}=35)$ & $24.2 \pm 4.9$ & $24.4 \pm 8.2$ & $58 \pm 13$ & $0.06 \pm 0.03$ \\
\hline $\begin{array}{l}\text { 何も使用 } \\
\text { していない }\end{array}(\mathrm{N}=83)$ & 24.4 & $24.4 \pm 5.7$ & 63 & $0.07 \pm 0.07$ \\
\hline$(\mathrm{N}=160)$ & $24.9 \pm 2.5$ & $24.8 \pm 2.5$ & $61 \pm 9$ & $0.09 \pm 0.09$ \\
\hline
\end{tabular}

表 2 環境適応手法ごとの就寝中の平均温熱環境

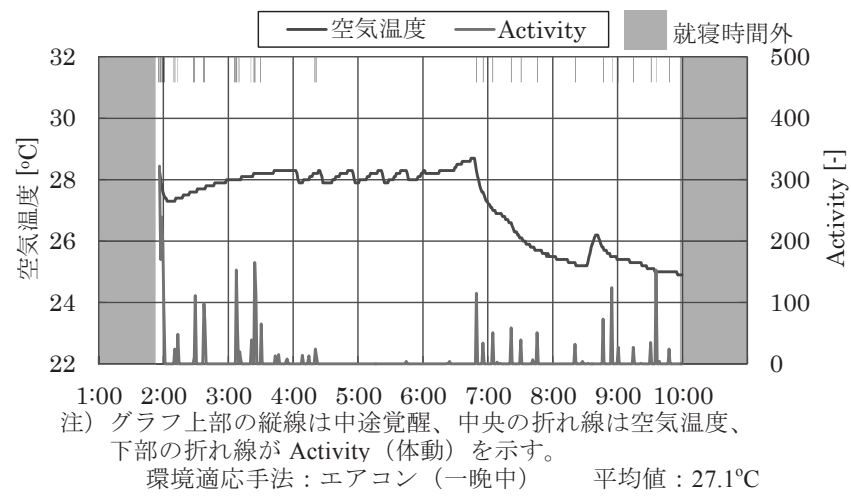

図 3 対象者 Cの代表日における空気温度の経時変化

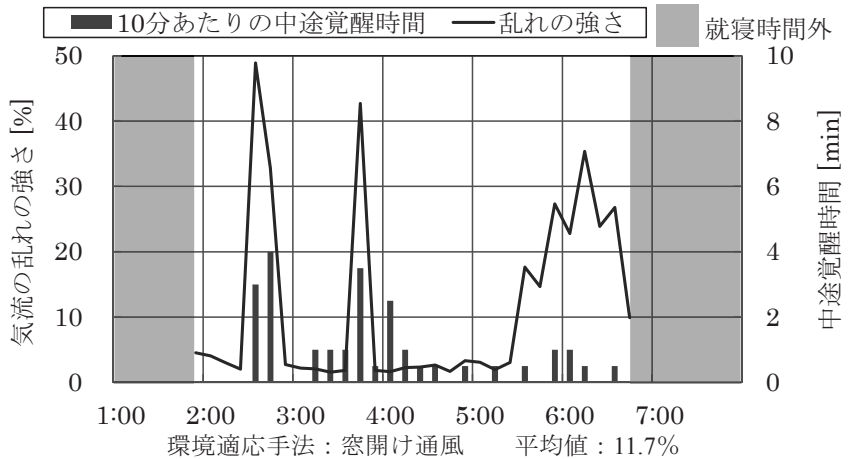

図 4 対象者 $\mathrm{A}$ の代表日における 10 分あたりの 気流の乱れの強さと中途覚醒時間の経時変化

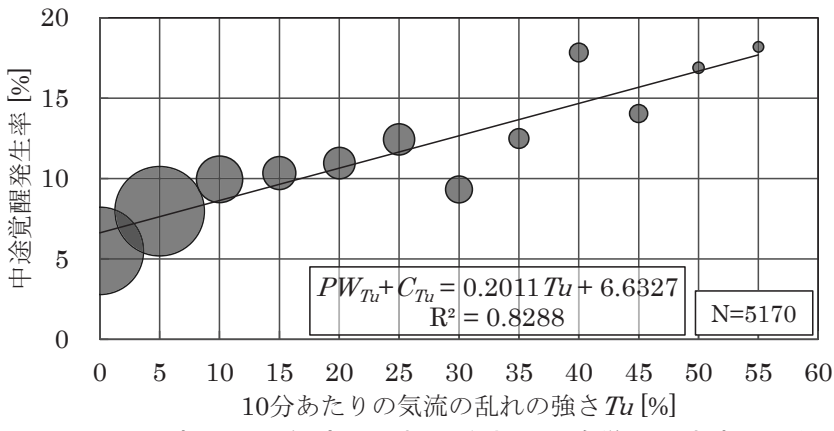

図 510 分あたりの気流の乱れの強さと中途覚醒発生率の関係

\section{2. 就寝中の人体熱負荷の算出}

1) 快適方程式

Lin ら 21) が提案した就寝時における快適方程式 22) を用いた。就 寝中の代謝熱産生量を $M=0.7 \mathrm{met}\left(=40 \mathrm{~W} / \mathrm{m}^{2}\right)$ 23)、就寝中の運動 による熱産生量を $W=0 \mathrm{~W} / \mathrm{m}^{2}$ と仮定すると発汗による潜熱損失量 
$E_{s w, r e q}$ は負の值となることから、就寝中の潜熱損失量 $E_{r s w}=0 \mathrm{~W} / \mathrm{m}^{2}$ としている。また、就床時の着衣と寝具の種類及び掛け方の申告か ら Lin ら 17)により測定された着衣と寝具の皮膚表面から環境まで の熱抵抗 (以下、熱抵抗) $I_{t}$ を参照した。着衣と寝具の熱抵抗は静 穏気流下で測定された值であるため、気流速度 $0.10 \mathrm{~m} / \mathrm{s}$ 未満のみを 分析対象とした。熱的中立状態における皮膚温 $t_{s k, r e q 、}$ 発汗蒸発放熱 量 $E_{r s w, r e q}$ 及び人体熱負荷 $L$ の算出式を式（3）～（5）に示す。

$$
t_{s k, r e q}=35.7-0.0275(M-W) \quad\left[{ }^{\circ} \mathrm{C}\right]
$$

$$
E_{r s w, r e q}=0.42(M-W-58.15) \quad\left[\mathrm{W} / \mathrm{m}^{2}\right]
$$$$
L=M-\left(\frac{1}{0.155 I_{t}}\left[\left(t_{s k}-\frac{h_{r} \bar{t}_{r}+h_{c} t_{a}}{h_{r}+h_{c}}\right)+w i_{m} L_{R}\left(p_{s k, s}-p_{a}\right)\right]\right.
$$

$$
+0.056\left(34-t_{a}\right)+0.692\left(5.87-p_{a}\right) \quad\left[\mathrm{W} / \mathrm{m}^{2}\right]
$$

$E_{r S W}:$ 発汗蒸発放熱量 $\left[\mathrm{W} / \mathrm{m}^{2}\right]$

$I_{t} \quad$ :皮膚表面から環境までの熱抵抗 $\left[\mathrm{W} /\left(\mathrm{m}^{2} \cdot \mathrm{K}\right)\right]$

$L$ : 人体熱負荷 $\left[\mathrm{W} / \mathrm{m}^{2}\right]$

$L_{R}$ :ルイス比 $[\mathrm{K} / \mathrm{kPa}]$

$M$ :代謝熱産生量 $\left[\mathrm{W} / \mathrm{m}^{2}\right]$

$W$ :仕事量 $\left[\mathrm{W} / \mathrm{m}^{2}\right]$

$h_{c}$ : 対流熱伝達率 $\left[\mathrm{W} /\left(\mathrm{m}^{2} \cdot \mathrm{K}\right)\right]$

$h_{r}$ : 放射熱伝達率 $\left[\mathrm{W} /\left(\mathrm{m}^{2} \cdot \mathrm{K}\right)\right]$

$i_{m}$ : 透湿効率 $[-]$

$p_{a}:$ 空気中の水蒸気圧 $[\mathrm{kPa}]$

$p_{s k, s}$ : 皮膚温の飽和水蒸気圧 $[\mathrm{kPa}] \quad t_{a}$ : 空気温度 $\left[{ }^{\circ} \mathrm{C}\right]$

$\overline{t_{r}}$ :平均放射温度 $\left[{ }^{\circ} \mathrm{C}\right]$

$t_{s k}:$ 平均皮膚温 $(=34.6)\left[{ }^{\circ} \mathrm{C}\right]$

$W$ : 皮膚濡れ率 $(=0.06)[-]$

注）添字 req は熱的中立状態における值を示す。

2）寝返りの影響

温熱環境の変化の影響を除外するために $\frac{d L}{d t}=0 \mathrm{~W} /\left(\mathrm{m}^{2} \cdot \min \right)$ であ る時刻のみを分析対象として、人体熱負荷 $L$ と中途覚醒発生率の関 係を分析した。人体熱負荷 $L$ を $5 \mathrm{~W} / \mathrm{m}^{2}$ 刻みに分類し、その区分内 での中途覚醒発生率の平均值を算出した。回帰した近似 2 次曲線は、 人体熱負荷 $L=5.88 \mathrm{~W} / \mathrm{m}^{2}$ の時に中途覚醒発生率が最も低くなり (図 7 の破線)、Haskel ら 7) の熱的中立状態における睡眠の質が良好と なるという研究結果に矛盾する結果となった。これは、寝返りによ る着衣と寝具の熱抵抗の低下が加味されていないためであると考え られる。そこで、着衣と寝具の熱抵抗 $I_{t}$ に熱抵抗補正係数 $\eta$ を乗じ、 寝返りの影響を考慮した人体熱負荷 $L$ 'を算出した。熱抵抗補正係 数 $\eta$ は、体動数と比例関係にあると仮定し、熱的中立状態 $\left(L^{\prime}=\right.$ $\left.0 \mathrm{~W} / \mathrm{m}^{2}\right)$ において中途覚醒発生率が最低となる值とした。体動数は Ohnaka ら 9) による若年者の空気温度と体動数の関係から人体熱負 荷 $L$ と体動数の関係を算出した。平均放射温度は空気温度と等しく、 相対湿度は $70 \%$ 、気流速度は静穏、着衣と寝具の熱抵抗は $2.36 \mathrm{clo}$ とした。人体熱負荷 $L$ と熱抵抗補正係数 $\eta$ の関係を式 (6) に示す。

$$
\begin{array}{lll}
\eta=1 & {[-]} & \left(L \leq-6.35\left[\mathrm{~W} / \mathrm{m}^{2}\right]\right) \\
\eta=1-0.0141 \times(L+6.35) & {[-]} & \left(L>-6.35\left[\mathrm{~W} / \mathrm{m}^{2}\right]\right)
\end{array}
$$

図 6 に本研究と Sakoi ら 24) の着衣と寝具の熱抵抗補正係数 $\eta$ の 比較を示す。Sakoi らの実験結果の人体熱負荷 $L$ ' は各実験条件を元 に式（5）より算出した。Sakoi らは $3^{\circ} \mathrm{C} 、 15^{\circ} \mathrm{C} 、 17^{\circ} \mathrm{C}$ の環境温度 における被験者実験の直腸温の実測值と人体熱モデルの解析值を比 較し、両值の乘離は寝返りによる着衣及び寝具の熱抵抗低下が原因 であるとし、本研究と同様に熱抵抗に補正係数 $\eta$ を乗じて直腸温の 実測值と解析值一致させている。Sakoi らの熱抵抗補正係数 $\eta$ も人 体熱負荷が増加するほど小さく、その大きさも本研究と概ね傾向は 一致したことから、熱抵抗補正係数 $\eta$ は妥当であると考えられる。

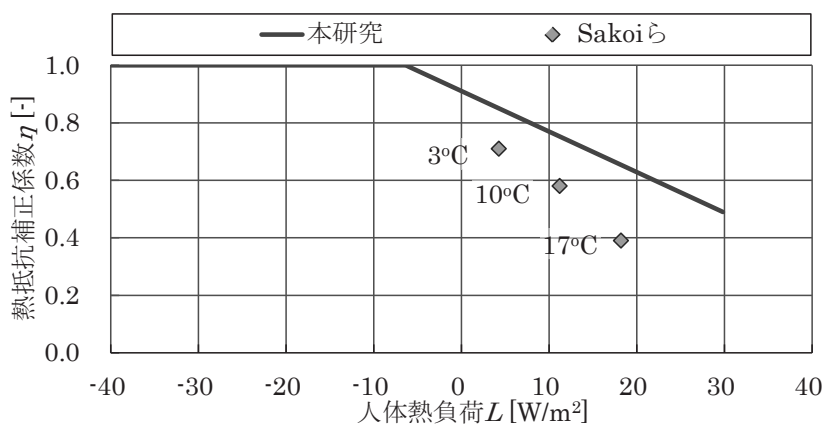

\begin{tabular}{|c|c|c|c|c|c|c|}
\hline 著者 & $\begin{array}{c}\text { 空気温度 } \\
{\left[{ }^{\circ} \mathrm{C}\right]}\end{array}$ & $\begin{array}{c}\text { 放射温度 } \\
{\left[{ }^{\circ} \mathrm{C}\right]}\end{array}$ & $\begin{array}{c}\text { 相対湿度 } \\
{[\%]}\end{array}$ & $\begin{array}{l}\text { 熱抵抗 } \\
\text { [clo] }\end{array}$ & $\begin{array}{c}\text { 人体熱負荷 } \\
{\left[\mathrm{W} / \mathrm{m}^{2}\right]}\end{array}$ & $\begin{array}{l}\text { 中途覚醒 } \\
\text { 発生率 [\%] }\end{array}$ \\
\hline \multirow{5}{*}{ Haskel et $\mathrm{al}^{7)}$} & 21.0 & - & 60 & 0.98 & -63.5 & 44.2 \\
\hline & 24.0 & - & 65 & 0.98 & -42.6 & 16.1 \\
\hline & 29.0 & - & 65 & 0.98 & -8.3 & 2.8 \\
\hline & 34.0 & - & 65 & 0.98 & 16.5 & 3.1 \\
\hline & 37.0 & - & 20 & 0.98 & 50.6 & 8.2 \\
\hline \multirow{3}{*}{ 川島、垣鍔 ${ }^{11)}$} & 28.0 & - & 65 & 2.07 & 3.5 & 3.4 \\
\hline & 30.0 & - & 65 & 2.07 & 8.8 & 5.4 \\
\hline & 28.0 & - & 80 & 2.07 & 4.2 & 3.0 \\
\hline \multirow{2}{*}{ 垣鍔、川島 ${ }^{12)}$} & 28.0 & - & 60 & 2.07 & 3.3 & 6.4 \\
\hline & 28.0 & - & 60 & 2.07 & 3.3 & 8.3 \\
\hline 森戸ら ${ }^{16)}$ & 26.4 & 26.1 & 53 & 2.07 & -0.5 & 5.8 \\
\hline Sewitch DE et $\mathrm{al}^{25)}$ & 27.0 & - & 65 & 0.98 & -22.1 & 8.8 \\
\hline \multirow{2}{*}{ Okamoto-Mizuno $^{26)}$} & 26.0 & - & 50 & 2.07 & -1.1 & 3.9 \\
\hline & 26.0 & - & 50 & 2.07 & -1.1 & 3.0 \\
\hline
\end{tabular}

図 6 本研究と既往研究との着衣と寝具の熱抵抗補正係数の比較

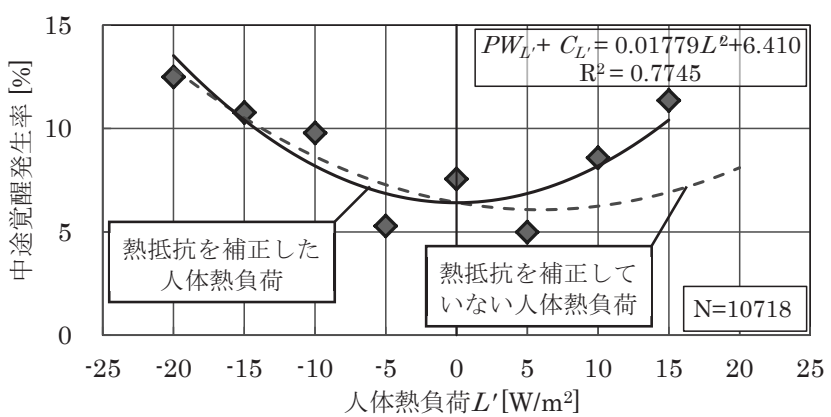

図 7 寝返りを考慮した人体熱負荷と中途覚醒発生率の関係 表 3 既往研究における実験条件と中途覚醒発生率

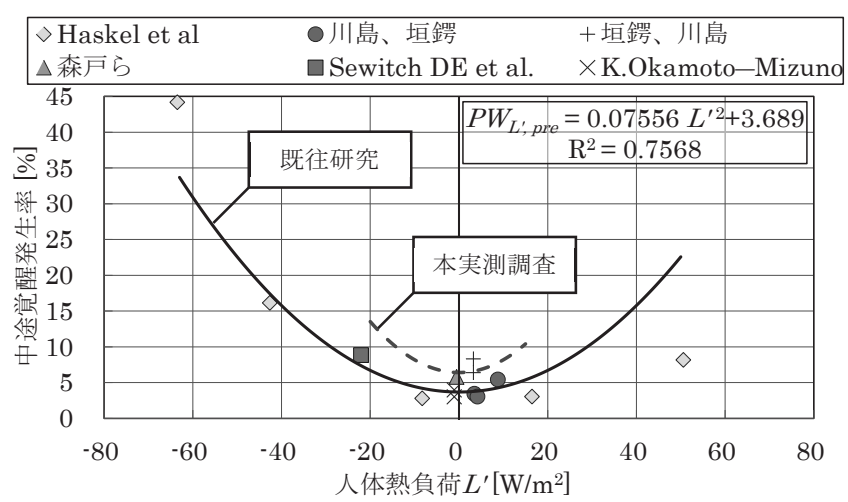

図 8 既往研究における人体熱負荷と中途覚醒発生率の関係

\section{3. 人体熱負荷が睡眠に及ぼす影響}

図 7 に寝返りを考慮した人体熱負荷 $L^{\prime}$ (以下、人体熱負荷）と中 途覚醒発生率の関係を示す。人体熱負荷 $L$ ’ $5 \mathrm{~W} / \mathrm{m}^{2}$ 刻みに分類し、 その区分内での中途覚醒発生率の平均值を示した。なお、プロット $1 つ に つ き 40$ 以上の測定数のもののみプロットした。図中の実線は プロットに対して軸を $0 \mathrm{~W} / \mathrm{m}^{2}$ として回帰した近似 2 次曲線を示す。 人体熱負荷 $L$ ' の絶対值が大きくなるほど中途覚醒発生率が高くな る強い相関関係が示され、暑さ寒さが覚醒刺激となることが示され 
た。近似曲線の切片は人体熱負荷 $L$, 以外の要素に起因する中途覚 醒発生率 $C_{L^{\prime}}(=6.410 \%)$ である。人体熱負荷 $L$, 起因する中途覚醒 発生率 $P W_{L}$ :

$$
P W_{L^{\prime}}=0.01779 L^{\prime 2} \quad[\%]
$$

表 3 に既往研究 7）11）12）16）25）26）における実験条件と中途覚醒発 生率、図 8 に表 3 に示した既往研究における人体熱負荷 $L$ ' と中途 覚醒発生率の関係を示す。静穏気流かつ定常状態の温熱環境で実験 が行われ、中途覚醒発生率が算出可能な既往研究を抽出した。着衣 と寝具の熱抵抗 $I_{t}$ は、Lin 5 17) の測定值を参照し、中途覚醒発生 率は単位時間あたりの中途覚醒時間（WASO/SPT）として、人体熱 負荷 $L$, に起因寸る中途覚醒発生率 $P W_{L^{\prime}, p r e}$ を算出した。既往研究に 比べ本研究の中途覚醒発生率の方が高かったが、既往研究において も人体熱負荷 $L$ ' の絶対值が大きくなるほど中途覚醒発生率が高く なる強い相関が示された。加えて、本実測調査結果から算出した人 体熱負荷 $L$ ' の範囲外の過酷な温熱環境における実験結果では、中 途覚醒発生率がさらに高かった。このように人体熱負荷 $L$ 'を用い て総合温熱環境を評価することにより、様々な条件の実験を同等に 比較し、温熱環境と睡眠の質の因果関係を分析することが出来る。

\section{4. 人体熱負荷の変化が睡眠に及ぼす影響}

図 9 に人体熱負荷 $L^{\prime}$ の変化率 $\frac{d L^{\prime}}{d t}$ と中途覚醒発生率の関係を示寸。 人体熱負荷 $L^{\prime}$ に起因寸る中途覚醒の影響を除外して、人体熱負荷 の変化率 $\frac{d L^{\prime}}{d t}$ の影響を分析するために人体熱負荷 $L$, に起因する中途 覚醒発生率 $P W_{L}$, と人体熱負荷 $L$, 以外の要素に起因寸る中途覚醒発 生率 $C_{L}$, 差し引いて、人体熱負荷の変化率 $\frac{d L^{\prime}}{d t}$ と中途覚醒発生率の 関係を算出した。人体熱負荷の変化率 $\frac{d L^{\prime}}{d t} \quad 0.2 \mathrm{~W} /\left(\mathrm{m}^{2} \cdot \mathrm{min}\right)$ 刻みに 分類し、その区分内での中途覚醒発生率の平均值を示した。なお、 プロット 1 つにつき 40 以上の測定数の場合のみプロットした。図 中の回帰曲線はプロットに対して軸を $0 \mathrm{~W} /\left(\mathrm{m}^{2} \cdot \mathrm{min}\right)$ 、切片を $0 \%$ と して回帰した近似 2 次曲線である。人体熱負荷の変化率 $\frac{d L^{\prime}}{d t}$ 絶対 值が大きいほど中途覚醒発生率が高く、就寝中の温熱環境の変化が 覚醒刺激となることが示された。人体熱負荷の変化率 $\frac{d L^{\prime}}{d t}$ 起因寸る 中途覚醒発生率 $P W_{\underline{d L^{\prime}}}$ は式（8）で表される。

$$
P W_{\frac{d L^{\prime}}{d t}}=5.889\left(\frac{d L^{\prime}}{d t}\right)^{2} \quad[\%]
$$

図 10 に既往研究の実験における人体熱負荷の変化率 $\frac{d L^{\prime}}{d t}$ と中途覚 醒発生率の関係を示寸。都築ら 27) は、実住宅の寝室を用いて、空 調条件の違いが睡眠に及ぼす影響の調査を目的として被験者実験を 行った。なお、実験条件における人体熱負荷 $L$ 'の分布が狭く、人 体熱負荷と中途覚醒発生率の関係は分析できなかった。人体熱負荷 の変化率 $\frac{d L^{\prime}}{d t}$ を $0.2 \mathrm{~W} /\left(\mathrm{m}^{2} \cdot \mathrm{min}\right)$ 刻みに分類し、その区分内での中途 覚醒発生率の平均值を示した。なお、プロット 1 つにつき 5 以上の 測定数のもののみプロットした。式（8）で表せる人体熱負荷の変 化率 $\frac{d L^{\prime}}{d t}$ に起因寸る中途覚醒発生率 $P W_{\underline{d L^{\prime}}}$ と同程度であり、 $L^{\prime}= \pm$ $0.6 \mathrm{~W} / \mathrm{m}^{2}$ では、中途覚醒発生率が顕著に高かった。既往研究におい ても本研究と同じように人体熱負荷の変化率 $\frac{d L^{\prime}}{d t}$ が大きいほど中途 覚醒発生率が高くなる傾向が示された。

\section{5. 着衣と寝具の熱抵抗と人体熱負荷の関係}

図 11 に着衣と寝具の熱抵抗 $I_{t}$ ごとの作用温度 $t_{o}$ と人体熱負荷 $L^{\prime}$ の関係を示す。Lin ら 17) が測定した着衣と寝具の組み合わせの範囲 $\left(0.98 \mathrm{clo} \leqq I_{t} \leqq 4.66 \mathrm{clo}\right)$ で着衣と寝具の調整を行うことにより、作

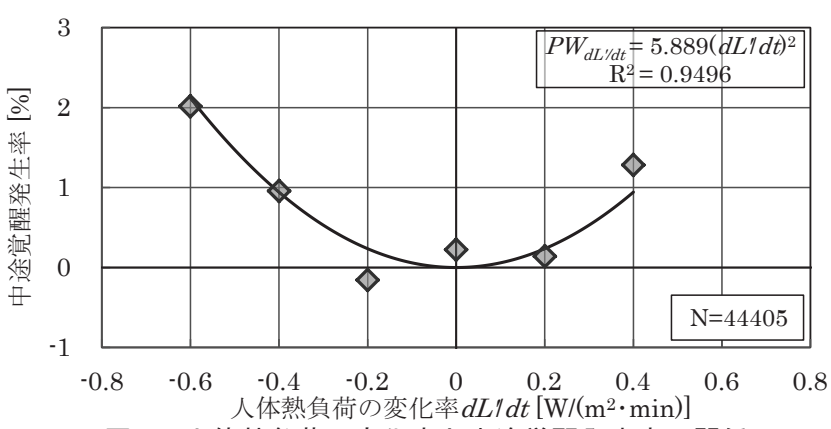

図 9 人体熱負荷の変化率と中途覚醒発生率の関係

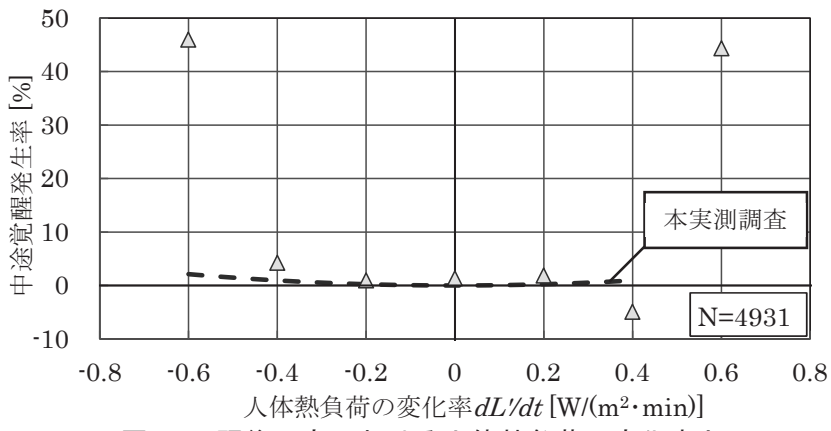

図 10 既往研究における人体熱負荷の変化率と 中途覚醒発生率の関係

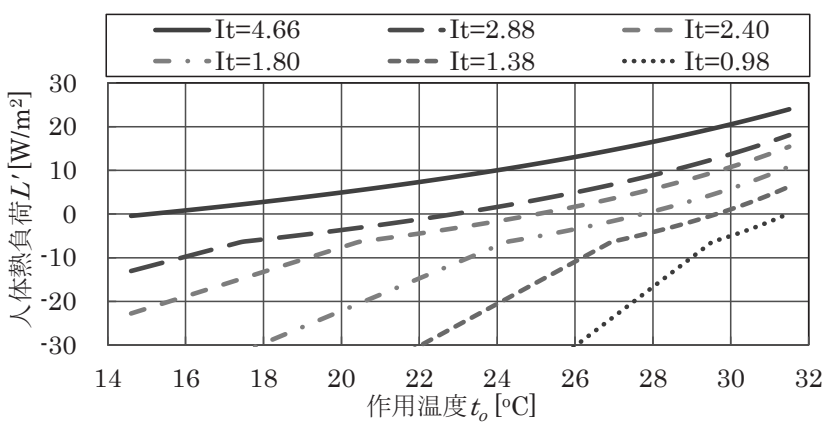

図 11 作用温度と人体熱負荷の関係

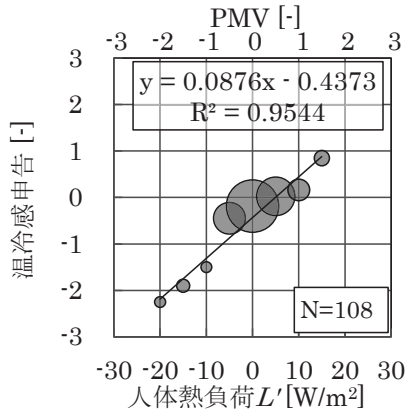

図 12 人体熱負荷と 温冷感の関係

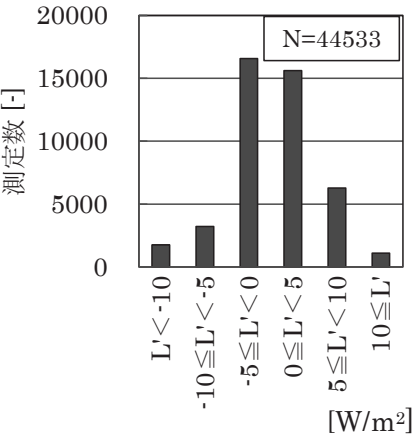

図 13 人体熱負荷の度数分布

用温度 $t_{o}$ が $15.0^{\circ} \mathrm{C}$ 未満から $31.4^{\circ} \mathrm{C}$ までの幅広い作用温度域におい て熱的中立状態に適応することが出来る。また、寝返りによる着衣 と寝具の熱抵抗の低下が生じる温熱環境において作用温度の変化に 対する人体熱負荷の変化が小さく、寝返りによる暑熱環境の緩和効 果を示している。

寝返りに起因する着衣と寝具の熱抵抗低下が生じない人体熱負荷 $L^{\prime}$ の範囲 $\left(L^{\prime} \leqq-6.35 \mathrm{~W} / \mathrm{m}^{2}\right)$ では、着衣と寝具の熱抵抗 $I_{t}$ が小さ いほど作用温度の変化に対する人体熱負荷の変化が大きいため、作 用温度の変化による中途覚醒が生じ易い。 


\section{6.＼cjkstart就寝中の人体熱負荷と心理量の関係}

図 12 に就寝中の PMV と温冷感の関係を示す。人体熱負荷 $L$, $5 \mathrm{~W} / \mathrm{m}^{2}$ 刻みに分類し、その区分内での就寝中の温冷感申告の平均值 を算出した。就寝中においても PMV と人体熱負荷 $L$, の関係が日中 と同じように成り立つとすると、就寝中の PMV と人体熱負荷 $L^{\prime}$ の 関係は式（9）で表される。

$$
P M V=L^{\prime}\left(0.303 e^{-0.036 M}+0.028\right) \leftleftarrows 0.10 L^{\prime}[-]\left(M=40\left[\mathrm{~W} / \mathrm{m}^{2}\right]\right) \quad \text { （9） }
$$

人体熱負荷から算出した PMV と就寝中の温冷感申告は概ね一致 しており、就寝中においても人体熱負荷 $L$ ' と温冷感の関係は、日 中と同様の関係が成り立つことが示された。

\section{7. 本実測調査における人体熱負荷とその変化率の割合}

図 13 に実測期間全体の人体熱負荷 $L$, の度数分布を示す。 $72.3 \%$ は人体熱負荷 $L, か ゙ \pm 5 \mathrm{~W} / \mathrm{m}^{2}$ の範囲内であったが、およそ $6.4 \%$ は $\pm 10 \mathrm{~W} / \mathrm{m}^{2}$ の範囲外の温熱環境であった。また、式（7）から算出し た人体熱負荷 $L$ 'に起因寸る一晚あたりの中途覚醒が睡眠時間に占 める割合は平均 $0.6 \%$ 、最大 $9.7 \%$ あった。多くの場合は熱的中立 状態を維持しているが、「エアコン」や「空開け通風」による冷え過 ぎが原因で睡眠の質が低下しやすい傾向がみられた。

式（8）から算出した人体熱負荷の変化率 $\frac{d L^{\prime}}{d t}$ に起因する一晚あた りの中途覚醒が睡眠時間に占める割合は、平均で $0.1 \%$ 、最大で $1.0 \%$ であった。人体熱負荷の変化率 $\frac{d L^{\prime}}{d t}$ に起因する中途覚醒時間の割合が 最大となったのは、着衣と寝具の熱抵抗が小さく $\left(I_{t}=1.80 \mathrm{clo}\right) 、 「$ 空 開け通風」により室内温湿度が変化していた場合であった。このよ うに寝具や環境適応手法の組み合わせ次第で、人体熱負荷 $L$ ' の变 動が生じて睡眠の質の低下を引起すことがある。

\section{6. まとめ}

1） 2013 年 9 月と 10 月に就寝中の環境適応手法の調查、温熱環境 心理量・生理量を測定した。実測対象者は様々な環境適応手法を用 いて就寝しており、温熱環境は常に変動していた。空気温度以外の 温熱要素の影響も加味するため、総合温熱環境とその変化が睡眠の 質へ及ぼす影響の因果関係を人体熱負荷を用いて分析した。

2）気流の乱れが強いほど中途覚醒発生率が高く、エアコンの発停 や空開け通風による気流の乱れが覚醒刺激となることが示された。

3）人体熱負荷 $L^{\prime}$ とその変化率 $\frac{d L^{\prime}}{d t}$ の絶対值が大きいほど中途覚醒 発生率が高くなることが示された。人体熱負荷 $L$, を用いて総合温 熱環境を評価することによって、既往研究における温熱環境と睡眠 の質の因果関係を整理した。

4）就寝中の PMV と温冷感は概ね一致し、就寝中においても人体熱 負荷 $L$ ' と温冷感は、日中と同様の関係が成り立つことが示された。

以上より、良質な睡眠を得るためには熱的中立状態に加え、気流 や温湿度が安定していることが必要であることが分かった。

\section{謝辞}

本研究は早稲田大学理工学研究所のプロジェクト【12L20】室内 空気質と熱的快適性に関する研究の一部として行われたものである。 科学研究補助金（基盤研究（A)）15H02280を受けた。

本研究を行うに際し、御議論・御協力頂いた、中野淳太先生（東 海大学 准教授)、河又大起氏 (当時 早稲田大学 大学院生)、都築弘 政氏（当時 早稲田大学 大学院生）に深く謝意を示します。

\section{参考文献}

1) Fabbri et al: Sleep and prospective memory, Biological Rhythm Research 2014, Vol.45, No.1, pp115-120, 2014

2) Pilcher et al: Sleep quality versus sleep quantity: Relationships between sleep and measures of health, well-being and sleepiness in college students, Journal of Psychosomatic Research, Vol.42, No.6, pp.583-596, 1997

3) Ogawa et al: Sweating during night sleep, The Japanese Journal of Physiology, Vol.17, pp.135-148, 1967

4）永井ら: 総説 体温調節と交感神経系地域制反応, 臨床生理, pp.357-365, 1973

5) Dewald et al: The influence of sleep quality, sleep duration and sleepiness on school performance in children and adolescents: A meeta-analytic review, Sleep Medicine Reviews Vol.14, pp.179-189, 2010

6）ダイキン工業株式会社：夏の睡眠と空気に関する調査結果, 2003

7) Haskel E.H. et al: The effects of high and low ambient temperatures on human sleep stages, Electroencephalography and Clinical Neurophysiology, Vol. 51, pp. 494-501, 1981

8) Muzet A et al: REM sleep and ambient temperature in man, Int. J. Neuroscience, Vol. 18, pp. 117-126, 1983

9) Ohnaka et al: Body movements of the elderly during sleep and thermal conditions in bedrooms in summer, journal of physiological anthropology, Vol.14 (2), pp.89-93, 1995

10）神田ら：夏季と秋季の温熱環境が若年者の睡眠中の体動に及ぼす影響, 群馬医短紀要, Vol.15, pp.19-23, 1994

11）川島ら：夏季の睡眠時における最適な冷房条件に関する実験的研究，人 間と生活環境, Vol.11, pp.17-23, 2004

12）垣鍔ら：体温のサーカディアンリズムを考慮した夏季の睡眠時の温熱 環境条件の評価, 日本生理人類学会誌, Vol.15, No.3, 2010

13）系井川ら：病室における睡眠時の天井放射冷房に関する実験的研究，人 間と生活環境, Vol.13, pp.87-93, 2006

14）川島ら：夏季の睡眠時における気流曝露の影響に関する実験的研究，人 間と生活環境, Vol.11, pp.25-30, 2004

15) Tsuzuki K. et al: Effects of airflow on body temperatures and sleep stages in a warm humid climate, International Biometeorol, Vol.52, pp.261-270, 2008

16）森戸ら：冷房の気流が睡眠と皮膚温に及ぼす影響 被験者実験による 冷房方法の比較, 空気調和・衛生工学会論文集, no.161, 2010

17) Lin ZP, Deng SM.: A study on the thermal comfort in sleeping environments in the bedding systems commonly used in the subtropics measuring the total insulation values for the bedding systems commonly used in the subtropics, Building and environment, vol.43, pp.905-916, 2008

18）石渡ら：頭部への動的温度制御により快眠効果の可能性，日本生理人類 学会誌, Vol.10 特別号 (1), pp.116-117, 2005

19）気象庁 http://www.data.jma.go.jp/obd/stats/etrn/ (参照 2013.10.30)

20) Fanger PO et al: Air turbulence and sensation of draught, Energy and building, vol.12, pp.21-39, 1988

21) Lin ZP, Deng SM.: A study on the thermal comfort in sleeping environments in the bedding systems commonly used in the subtropics -Developing a thermal comfort model for sleeping environments, Building and environment, vol.43, pp.905-916, 2008

22) Fanger P. O.: Thermal Comfort, Danish Technical Press, Copenhagen, 1970

23) ASHRAE: ASHRAE Handbook of Fundamentals, 1993 8, 8 table 4)

24) Sakoi et al: Behavioral thermoregulation during human sleep deduced from heat transfer analysis, Indoor air 2011

25) Sewitch DE et al: Body Temperature and Sleep Architecture in Response to a Mild Cold Stress in Women, Physiology and Behavior, Vol.36, pp.951-957, 1986

26) Okamoto-Mizuno K et al: Effects of partial humid heat exposure during different segments of sleep on human sleep stages and body temperature, Physiology and behavior, Vol.83, pp.759-765, 2005

27）都築ら：床下冷気を利用した夏季寝室の温熱環境と睡眠の質に関する 検討，その 2 被験者実験による心理量・生理量測定結果，日本建築学会大 会学術講演梗概集 D-2 環境工学 II, pp.397-398, 2013 


\title{
EFFECTS OF THERMAL LOAD AND ITS VARIATION ON SLEEP
}

\author{
Ken UNNO* Emika MIYAKE** and Shin-ichi TANABE ${ }^{* * *}$ \\ * Kajima Corporation. \\ (Former Grad. Stud., Dept. of Architecture, Waseda University) \\ ** Grad. Stud., Dept. of Architecture, Waseda University \\ *** Prof., Dept. of Architecture, Waseda University, Dr. Eng.
}

Recently, sleep disorder has been becoming a serious health problem. Out of the many factors affecting sleep disorder, thermal environment is one of the strongest. Thermoregulation deteriorates during the REM stage of sleep, causing a decline in the amount of REM sleep when outside the range of thermal neutrality. A reduced amount of REM sleep results in reduced work efficiency during the day. In Japan, most people sleep with an air conditioner, fan, or natural ventilation during the summer season. However, the thermal environment created by these measures is not necessarily good for sleep. Many studies have examined only the impact of temperature and humidity on good sleep; very few studies have focused on the effect of the total thermal environment, which includes the factors of air temperature, relative humidity, air velocity, mean radiant temperature, metabolic rate and total insulation value in its calculations. In this study, a field survey was carried out to investigate the thermal environment in bedrooms. The effect of air turbulence on sleep was first investigated as a representative thermal stimulus. Next, in order to take into account all six factor of thermal environment, the thermal load on the body and its variation were calculated and their effects on sleep were evaluated.

The field survey was carried out in September and October 2013 in 16 bedrooms of 16 different residences. Air temperature, relative humidity, globe temperature, and air velocity were measured continuously during the sleep sessions for five consecutive nights. Subjects provided information about the types of blankets used and their impression of the thermal environment and sleep quality in questionnaires administered before and after the sleep session. In addition, all subjects wore an Actiwatch to calculate the duration of wakefulness and sleep efficiency.

The average air velocity during the night had no significant impact on sleep quality; however, an increase in air turbulence caused an increase in the duration of wakefulness. To further evaluate the effects of the variation in air velocity and to take into account the other factors of thermal environment, the thermal load on the body was calculated. We altered several conditions of the comfort equation for sleep and used the adjusted equation for our analysis. Only the data that satisfied the condition of air velocity below $0.1 \mathrm{~m} / \mathrm{s}$ were used, since the total insulation values were calculated under still air. In addition, to include the effect of body movement during sleep, we developed a correcting coefficient for the total insulation value. After applying this correcting coefficient, the relationship between the heat load on the body and the probability of awakening was evaluated. We found that both negative and positive increase in the heat load on the body causes an increase in the probability of awakening. An increase in the variation of the heat load on the body also resulted in an increase in the probability of awakening.

We conclude that it is important to evaluate the effect of the total thermal environment and to take into account the effect of its variation when planning a pleasant thermal environment for sleep. In future studies, it is necessary to consider local heat stimulation and air drafts as potential causes of sleep disruption. 